\title{
Memilah Memilih dan Mengolah Sampah Rumah Tangga [Organik-An Organik : Palstik, Logam, Kertas] Bersama Kader Pendamping Tanggap Bocah di Kecamatan Sleman
}

\author{
Selecting and Processing Household Waste with The Response Child \\ Administrative Kader in Sleman District
}

\author{
${ }^{1}$ Naris Dyah Prasetyawati, ${ }^{2}$ Sigid Sudaryanto, ${ }^{3}$ Sri Puji Ganefati \\ 1,2,3 Jurusann Kesehatan Lingkungan Politeknik Kesehatan Kementerian Kesehatan Yogyakarta Jl.Tata \\ Bumi No. 3 Banyuraden Gamping Sleman Yogyakarta \\ email Korespondensi : narisdyahprasetyawati@gmail.com, agustinus_sigid@yahoo.com
}

\begin{abstract}
Kejadian Demam Berdarah Dengue sangat erat kaitannya dengan faktor lingkungan, yaitu tersedianya tempat berkembangbiak (breeding place) vektor nyamuk Aedes aegypti. Sampah yang paling berbahaya adalah sampah anorganik, hal ini dikarenakan sampah jenis ini sulit diurai oleh bakteri atau dekomposer. Salah satu sampah anorganik yang membutuhkan penanganan khusus dalam mengelola dan mengolahnya adalah sampah plastik. Sifat dari sampah plastik adalah tidak mudah diurai, proses pengelolaannya menimbulkan toksik dan bersifat karsinogenik serta membutuhkan waktu yang sangat lama untuk bisa terurai secara alamiah. Kegiatan ini bertujuan untuk meningkatkan pengetahuan tentang cara mengelola sampah plastik rumah tangga yang dihasilkan kepada anak-anak anggota Tanggap Bocah melalui kader pendamping Tanggap Bocah di Kecamatan Sleman Kabupaten Sleman Yogyakarta. Kegiatan pengabdian kepada masyarakat di Puskesmas Sleman dilakukan di wilayah Desa Trimulyo yang merupakan bagian dari wilayah kerjanya. Kegiatan berlangsung dengan lancar dan sukses. Pengetahuan peserta semakin bertambah dengan diberikannya materi penyuluhan ini, hal ini dibuktikan dengan sesi diskusi pada akhir kegiatan dengan memberikan pertanyaan pemicu peserta mampu menjelaskan untuk materi intinya. Kelanjutan pembinaan dan pemantauan terhadap kader dan anggota tanggap bocah diserahkan kepada pihak Puskesmas. Tindak lanjut dari kegiatan ini adalah kader pendamping melakukan pelatihan dan penyampaian infromasi kepada anggota Tanggap Bocah di wilayahnya masing-masing Kata Kunci : DBD, Tanggap Bocah, Sampah Rumah Tangga, Kader Pendamping
\end{abstract}

\begin{abstract}
The incidence of Dengue Hemorrhagic Fever is closely related to environmental factors, namely the availability of breeding grounds for the Aedes aegypti mosquito vector. The most dangerous waste is inorganic waste, this is caused by the type of waste that is difficult to decompose or decompose. One of the inorganic waste that requires special handling in managing and processing is plastic waste. The nature of plastic waste is that it is not easy to decompose, the management process is toxic and carcinogenic and takes a very long time to decompose naturally. This activity aims to increase knowledge about how to manage household plastic waste generated for the children of Tanggap Bocah members through the assistant cadres of Tanggap Bocah in Sleman District, Sleman Regency, Yogyakarta. Community service activities at the Sleman Health Center are carried out in the Trimulyo Village area which is part of its working area. The activity went smoothly and successfully. The knowledge of the participants was increased by the provision of this counseling material, this was evidenced by the discussion session at the end of the activity by asking questions that triggered the participants to be able to explain the material. Continuing coaching and monitoring of cadres and responsive members are left to the Puskesmas. The follow-up to this activity is for the companion cadres to conduct training and deliver information to the members of Responding Bocah in their respective areas
\end{abstract}

Keywords: DHF, Child Response, Household Waste, Companion Cadre 


\section{Pendahuluan}

Kejadian penyakit Demam Berdarah yang terjadi Indonesia terjadi di hampir seluruh wilayah Provinsi. Menurut Kemenkes RI (2020) jumlah kasus DBD yang terjadi hingga bulan Juli mencapai 71.633 kasus. Kemudian dilaporkan juga 10 Provinsi dengan jumlah kasus terbanyak sebagian besar berada di Pulau Jawa dan Yogyakarta termasuk di dalamnya dengan 2.720 kasus. Kejadian ini selalu terjadi setiap tahunnya dan berpotensi menjadi endemis pada setiap tahunnya. Walaupun jumlah kasus dan kematiannya lebih rendah dibandingka pada Tahun 2019 akan tetapi tetap harus menjadi suatu kewaspadaan tersendiri. Hal ini juga disebabkan karena berbarengan dengan pandemi Covid 19 yang membuat fokus kewaspadaan menjadi sedikit berkurang di masyarakat.

Menurut Rosmala F dkk (2019) kejadian Demam Berdarah Dengue sangat erat kaitannya dengan faktor lingkungan, yaitu tersedianya tempat berkembangbiak (breeding place) vektor nyamuk Aedes aegypti. Penampungan air yang berada baik di dalam maupun di luar rumah atau bangunan dalam jumlah yang banyak merupakan breeding place yang sangat mendukung untuk bertelur dan berkembangbiak. Selanjutnya disampaikan apabila jumlah breeding place tersebut semakin banyak maka semakin meningkat juga risiko kejadian DBD di lingkungan tersebut. Hasil penelitian tersebut juga menyatakan bahwa ada hubungan yang bermakna antara faktor risiko lingkungan dalam pengelolaan sampah padat dengan kejadian DBD.

Sampah yang paling berbahaya adalah sampah anorganik, hal ini dikarenakan sampah jenis ini sulit diurai oleh bakteri atau dekomposer. Salah satu sampah anorganik yang membutuhkan penanganan khusus dalam mengelola dan mengolahnya adalah sampah plastik. Sifat dari sampah plastik adalah tidak mudah diurai, proses pengelolaannya menimbulkan toksik dan bersifat karsinogenik serta membutuhkan waktu yang sangat lama untuk bisa terurai secara alamiah (Fauzi A, 2018). Selanjutnya disampaikan bahwa Indonesia merupakan penghasil sampah plastik kelaut terbesar kedua di dunia. Padahal apabila dapat dikelola dengan baik dari 48 ton sampah plastik yang diolah dapat mendatangkan keuntungan sebesar Rp.16.379.472 per bulan (www.maritim.go.id).

Menurut penelitian yang dilakukan Jenna R Jambeck dari University of Georgia, pada 2010 ada 275 juta ton sampah plastik yang dihasilkan di seluruh dunia. Sekitar 4,8-12,7 juta ton di antaranya terbuang dan mencemari laut. Indonesia memiliki populasi pesisir sebesar 187,2 juta yang setiap tahunnya menghasilkan 3,22 juta ton sampah plastik yang tak terkelola dengan baik. Sekitar 0,48-1,29 juta ton dari sampah plastik tersebut diduga mencemari lautan. Data itu juga mengatakan bahwa Indonesia merupakan negara dengan jumlah pencemaran sampah plastik ke laut terbesar kedua di dunia. Cina memimpin dengan tingkat pencemaran sampah plastik ke laut sekitar 1,23-3,53 juta ton/tahun.

Berdasarkan data dari Asosiasi Industri Plastik Indonesia (INAPLAS) dan Badan Pusat Statistik (BPS) menunjukkan sampah plastik di Indonesia mencapai 64 juta ton per tahun. Sebanyak 3,2 juta ton di antaranya merupakan sampah plastik yang dibuang ke laut. Sumber yang sama menyebutkan, kantong plastik yang terbuang ke lingkungan sebanyak 10 miliar lembar per tahun atau sebanyak 85.000 ton kantong plastik.

Sampah yang tidak dikelola dengan baik seperti sampah bekas minuman, gelas, kaleng dan dibuang di sembarang tempat dapat menjadi wadah yang menampung air hujan. Jika wadah tersebut sudah ada air di dalamnya maka lambat laun akan menjadi tempat perindukan dan berkembangbiak nyamuk Aedes aegypti. Nyamuk tersebut menyukai tempat perindukan yang tenang dengan air bersih dan tidak bersentuhan langsung dengan tanah, sehingga sampahsampah yang dibuang sembarangan dalam keadaan terbuka merupakan tenmpat perindukan yang nyaman bagi nyamuk Aedes aegypti. 
Berdasarkan uraian tersebut maka kegiatan Pengabdian kepada masyarakat ini mengambil tema mengenai pengelolaan sampah plastik di rumah tangga. Hal ini dikarenakan rumah tangga sebagai satuan unit penghasil sampah terkecil yang ada di masyarakat. Kegiatan ini bertujuan untuk meningkatkan pengetahuan tentang cara mengelola sampah plastik rumah tangga yang dihasilkan kepada anak-anak anggota Tanggap Bocah melalui kader pendamping Tanggap Bocah di Kecamatan Sleman Kabupaten Sleman Yogyakarta

\section{Metode dan Waktu Pelaksanaan}

Kegiatan pengabdian kepada masyarakat ini menggunakan metode penyuluhan, diskusi, dan praktik sederhana memanfaatkan sampah plastik. Media berupa video presentasi dan bahan praktik. Peserta kegiatan ini rencananya adalah kelompok anak-anak anggota Tanggap Bocah yang dipilih oleh petugas sanitasi Puskesmas di wilayah kerja Puskesmas Sleman sebanyak 30 peserta, akan tetapi dikarenakan kondisi pandemi maka yang diberikan pendampingan adalah Kader Tanggap Bocah di Kecamatan Sleman juga sebanyak 30 peserta. Kegiatan dilaksanakan pada Hari Jum'at 17 Juli 2020.

\section{Hasil dan Pembahasan}

Pada kegiatan ini didahului dengan penelitian dengan judul Analisis Pelaksanaan Program Tanggap Bocah Terhadap Angka Kejadian DBD dan Pencapaian PHBS di Kecamatan Sleman. Kegiatan ini pada awalnya direncanakan untuk anak-anak anggota Tanggap Bocah, akan tetapi pada perjalanan waktu terjadi pandemi Covid 19 yang mengharuskan untuk melakukan pembatasan sosial berskala besar sehingga meniadakan kegiatan berkumpul dalam jumlah peserta yang banyak, menutup sekolah dan kegiatan perkantoran sehingga mengharuskan kita untuk bekerja, belajar dan beribadah dari rumah. Dengan kondisi tersebut maka sasaran kemudian dirubah menjadi kader pendamping anggota Tanggap Bocah, pelaksanaan kegiatan juga menunggu kondisi lebih memungkinkan sehingga bisa diadakan pertemuan dan sesuai dengan protokol kesehatan.

Setelah disepakati waktu untuk melakukan kegiatan kemudian dilakukan koordinasi dengan bagian Kesra Desa Trimulyo Sleman. Pihak dari desa meminta untuk dilaksanakan hanya pada kader dewasa dan tidak memberikan rekomendasi untuk mengumpulkan anak-anak. Sehingga kegiatan ini kemudian hanya melibatkan kader dewasa dengan penerapan protokol kesehatan yang ketat. Peserta dengan adanya gangguan kesehatan yang berpotensi menularkan kepada peserta lain tidak diperbolehkan mengikuti kegiatan ini. Peserta juga wajib menggunakan masker ketika acara berlangsung, Jumlah peserta yang dapat hadir sudah dikonfirmasi oleh Puskesmas Sleman sehingga tidak melebihi kuota yang disediakan

\section{Pelaksanaan Kegiatan}

Kegiatan dimulai pada Pukul 08.00 di Balai Desa Trimulyo Sleman. Penggunaan balai desa ini dikarenakan memiliki luas ruangan yang memenuhi syarat, sehingga dapat mengatur posisi duduk peserta dengan jarak 1,5-2 $\mathrm{m}$ antara peserta yang satu dengan yang lainnya. Hadir dalam acara ini adalah koordinator kesra dan staf bidang kesra Kelurahan Trimulyo Sleman serta petugas UKM dari Puskesmas Sleman 


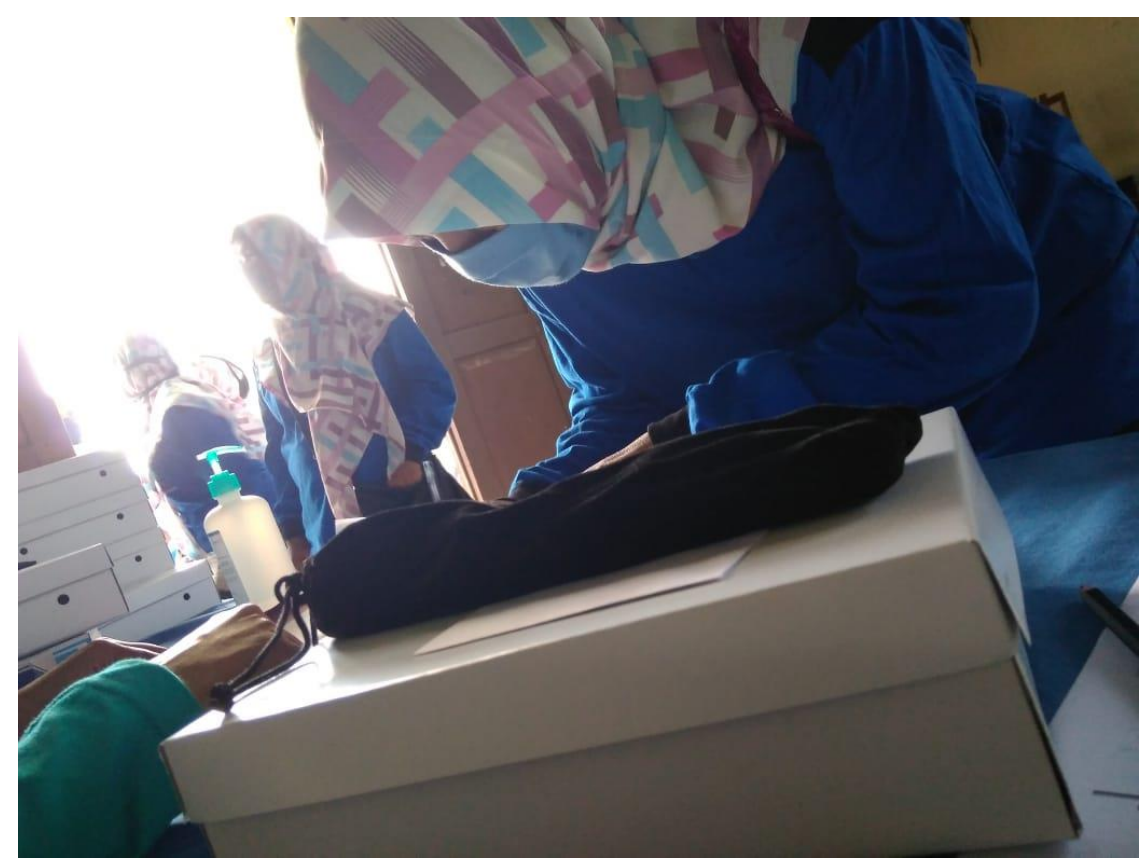

Gambar 1. Peserta hadir wajib mengisi daftar kehadiran

Peserta yang hadir wajib untuk mencuci tangan dengan sabun dan air mengalir di luar ruangan, menggunakan masker dan di cek suhu tubuhnya. Setelah itu kemudian mengisi daftar kehadiran dan menerima bahan kontak kemudian membasuh tangan dengan hand sanitizer yang sudah disediakan. Konsumsi yang diberikan tidak boleh dikonsumsi di lokasi, untuk meminimalisir membuka masker ketika acara berlangsung

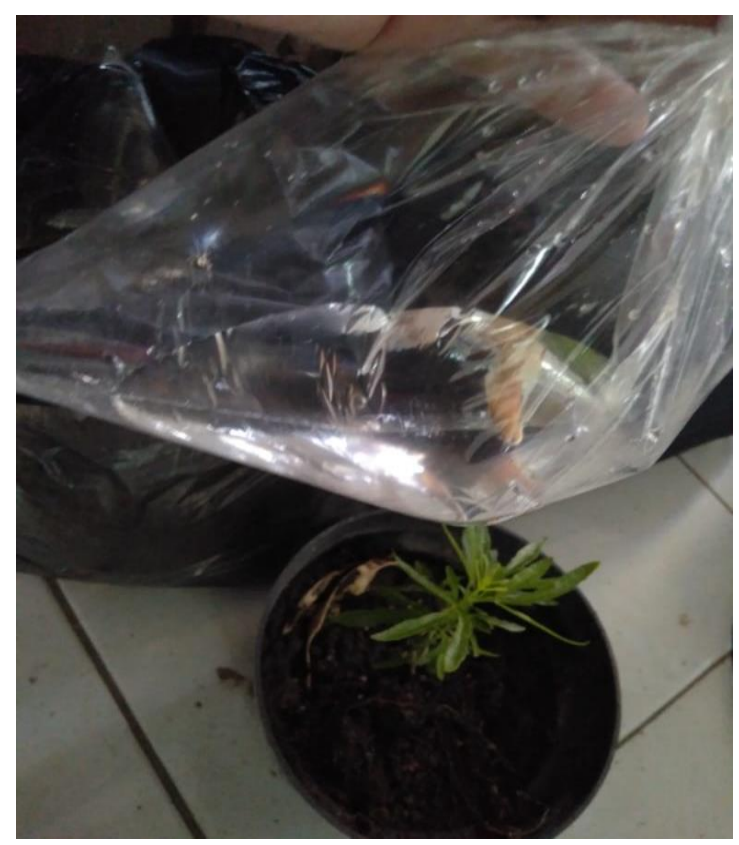

Gambar 2. Ikan Cupang dan Pohon Zodia sebagai salah satu materi yang disampaikan

Pemanfataan ikan cupang dan pohon zodia sebagai ikan pemakan jentik dan tanaman anti nyamuk yang dapat ditanam dan dipelihara di lingkungan keluarga. Dengan memanfaatkan barang bekas misalnya pot dari bekas botol air mineral dan botol kaca untuk memelihara ikan cupang. Peserta yang aktif dalam diskusi dan yang sudah melakukan pengolahan sampah di 

Syifa

AS-SYIFA: Jurnal Pengabdian dan Pemberdayaan Kesehatan Masyarakat

lingkungan keluarga nya minimal memilah sampah diberikan reward ikan cupang dan tanaman zodia tersebut. Dalam kegiatan ini juga disampaikan materi tentang bagaimana pentingnya untuk mulai mengurangi sampah plastik dalam kehidupan sehari-hari dengan mengganti piranti plastik yang sering digunakan sekali pakai dengan yang beberapa kali pakai, misalnya mengganti kebiasaan membeli minuman dengan botol sekali pakai dengan menggunakan tumbler, mengganti sedotan sekali pakai dengan memberikan bahan kontak berupa sedotan dari besi serta mensosialisasikan cara memilah sampah mulai dari sumber penghasilnya.

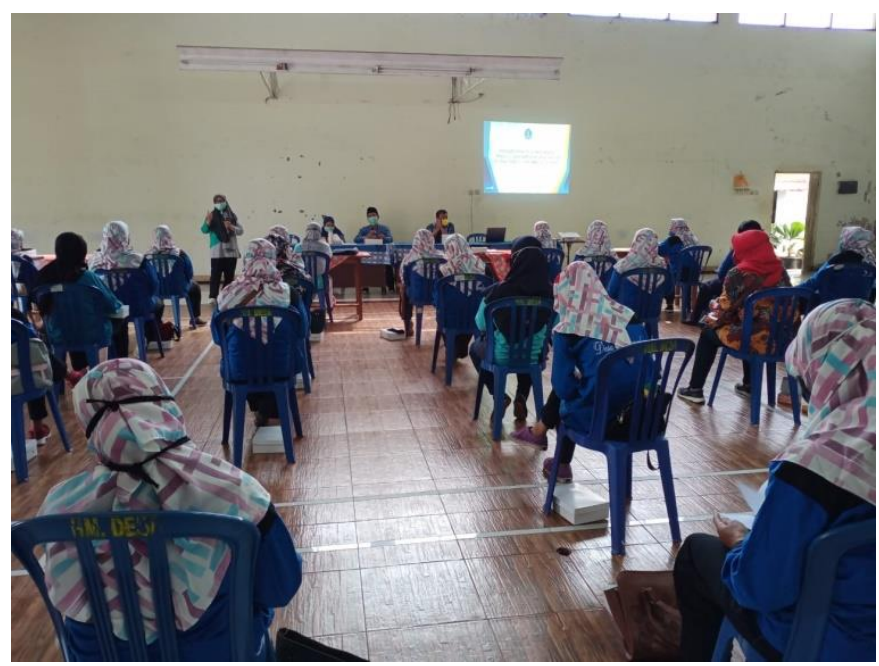

Gambar 3. Pengarahan dari Petugas UKM Puskesmas Sleman

Petugas UKM dari Puskesmas Sleman memberikan pengarahan tentang penularan Covid 19 dan kemungkinan peningkatan kasus demam berdarah di wilayah Kecamatan Sleman. Pengarahan lain juga diberikan berkaitan dengan CITAMASJAJAR yang merupakan kependekan dari cuci tangan, memakai masker dan menjaga jarak. Semua peserta dan kegiatan ini sudah dilaksanakan dengan ketentuan tersebut. Dukungan Puskesmas Sleman untuk kegaiatan ini juga dilakukan dengan memberikan tambahan suplemen untuk multivitamin yang diberikan kepada peserta.

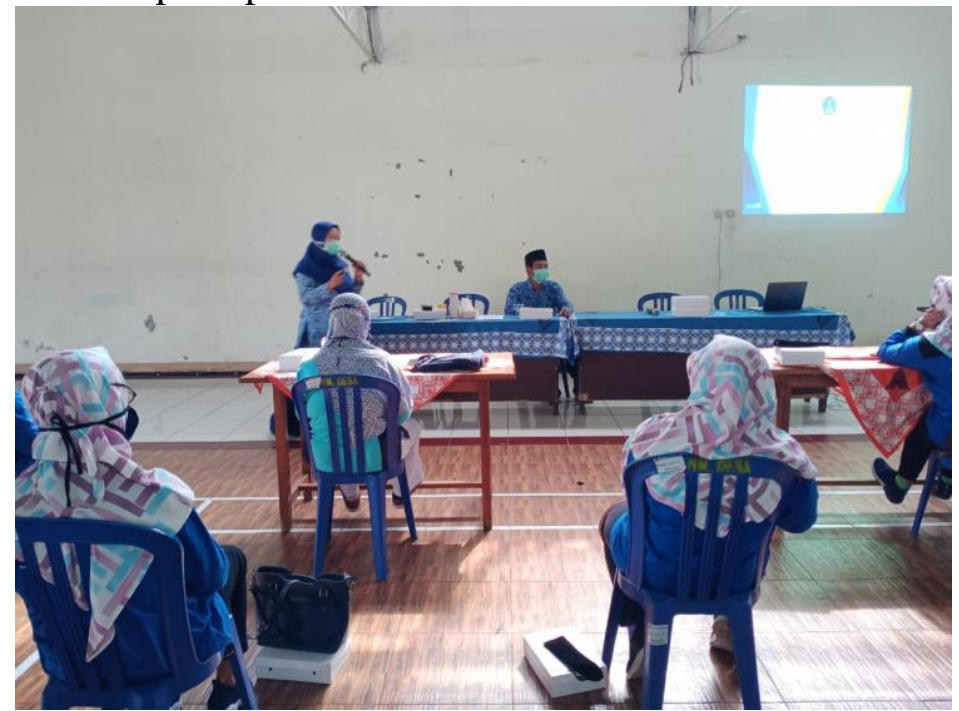

Gambar 4. Penyampaian Materi Pengabdian Kepada Masyarakat 
Materi yang disampaikan tentang memilah, memilih dan mengolah sampah plastik di rumah tangga. Penekanan pada pemanfaatan sampah plastik rumah tangga yang bisa digunakan kembali dan bagaimana mengelolanya. Media yang digunakan adalah power point dan video tentang pengolahan sampah. Tanya jawab dan diskusi dengan peserta juga dilakukan dalam sesi ini. Selama kegiatan berlangsung seluruh peserta, narasumber dan tamu undangan dilarang untuk membuka masker.

Dalam diskusi ini dapat diketahui bahwa sudah dijalankan adanya bank sampah di salah satu RT di wilayah Desa Trimulyo, akan tetapi beberapa kendala ditemui dalam menjalankannya. Hambatan yang ditemui, antara lain: jumlah nasabah yang terus menurun juga kesulitan dari pengelola untuk menjaga semangat anggota dalam menabung sampah. Kader juga sudah mulai melakukan pemilahan sampah dan pemanfaatan kembali sampah rumah tangga yang tidak digunakan kembali. Contoh penggunaan bekas bungkus minyak goreng untuk pembuatan polybag tanaman sayur dan tanaman obat keluarga, bekas botol air mineral untuk pot tanaman hias. Dalam kegiatan ini upaya sosialisasi untuk mulai mengurangi sampah plastik adalah dengan menggunakan sedotan besi sebagai pengganti sedotan plastik yang sudah sangat familiar digunakan oleh masyarakat.

Evaluasi dilaksanakan dengan melibatkan pihak Puskesmas, untuk mengetahui bagaimana kegiatan ini mendukung Program kegiatan yang dilakukan di Puskesmas Sleman. Membahas tentang hambatan dan kekurangan yang ditemui ketika pelaksanaan kegiatan. Kelanjutan pembinaan dan pemantauan terhadap kader dan anggota tanggap bocah diserahkan kepada pihak Puskesmas. Tindak lanjut dari kegiatan ini adalah kader pendamping melakukan pelatihan dan penyampaian infromasi kepada anggota Tanggap Bocah di wilayahnya masingmasing.

\section{Kesimpulan dan Saran}

Kegiatan pengabdian kepada masyarakat di Puskesmas Sleman dilakukan di wilayah Desa Trimulyo yang merupakan bagian dari wilayah kerjanya. Kegiatan berlangsung dengan lancar dan sukses. Pengetahuan peserta semakin bertambah dengan diberikannya materi penyuluhan ini, hal ini dibuktikan dengan sesi diskusi pada akhir kegiatan dengan memberikan pertanyaan pemicu peserta mampu menjelaskan untuk materi intinya. Kelanjutan pembinaan dan pemantauan terhadap kader dan anggota tanggap bocah diserahkan kepada pihak Puskesmas. Saran dan tindak lanjut dari kegiatan ini adalah kader pendamping melakukan pelatihan dan penyampaian infromasi kepada anggota Tanggap Bocah di wilayahnya masingmasing

\section{Ucapan Terimaksih}

Ucapan terimakasih penulis sampaikan kepada Kepala Puskesmas Sleman beserta tim UKM Puskesmas Sleman, Penewon Sleman beserta jajarannya, Kepala Desa dan Kader Desa Trimulyo Kepanewon Sleman Yogyakarta. Ucapan terimakasih juga penulis sampaikan kepada Poltekkes Kemenkes Yogyakarta yang telah memberikan dukungan dana untuk kegiatan pengabdian kepada masyarakat ini. 
AS-SYIFA: Jurnal Pengabdian dan Pemberdayaan Kesehatan Masyarakat

\section{Daftar Pustaka}

Fauzi, Abror, 2018. Indonesia Darurat Sampah Plastik diunduh dari http://indonesiabaik.id/infografis/indonesia-darurat-sampahplastik\#: : :text=Sifat\%20sampah\%20plastik\%20tidak\%20mudah,tahun\%20bila\%20teru rai\%20secara\%20alami.\&text=Jika\%20diolah\%20dengan\%20baik\%2C\%20sampah,pro duksi\%2048\%20ton\%20sampah\%20plastik.

Kemenkes RI, 2020. Hingga Juli, Kasus DBD di Indonesia Capai 71 ribu diunduh dari https://www.kemkes.go.id/article/view/20070900004/hingga-juli-kasus-dbd-diindonesia-capai-71-ribu.html

Lingkungan Hidup, 2019. Menenggelamkan Pembuang Sampah Plastik di Laut diunduh dari https://www.indonesia.go.id/narasi/indonesia-dalam-angka/sosial/menenggelamkanpembuang-sampah-plastik-dilaut\#: :text=Data\%20Asosiasi\%20Industri\%20Plastik\%20Indonesia,plastik\%20yang\% 20dibuang\%20ke\%20laut.

Rosmala F, Rosidah I, 2019. Hubungan Faktor Risiko Kesehatan Lingkungan Dalam Pengelolaan Sampah Padat Dengan Kejadian Demam Berdarah Jurnal Kesehatan Komunitas Indonesia Volume 15 No. 1 Maret 2019 
